\title{
Effect of Active Learning Technique on Self-Concept and Academic Achievement Among Juniour Secondary School Students in Geometry in Bosso, Niger State, Nigeria
}

\author{
Aliyu Alhaji ZAKARIYYA (Ph.D) ${ }^{1}$ Ahmad Umar MANKO(Ph.D $)^{2}$, Kure D. ISAH ${ }^{3}$, Ochidali Apollos ADUOJO ${ }^{4}$ \\ ${ }^{183}$ Department of Science Education, Ibrahim Badamasi Babangida University, Lapai, Niger State, Nigeria \\ ${ }^{2 \& 4}$ Department of Mathematics, Niger State College of Education, Minna, Nigeria
}

\begin{abstract}
Publication Issue
Article Info

Volume 8, Issue 6

Page Number : 170-177

November-December-2021
\end{abstract}

\section{Article History}

Accepted : 01 Nov 2021

Published : 14 Nov 2021

\section{ABSTRACT}

This study investigated the effect of active learning technique on self-concept and academic achievement in geometry among junior secondary school students in Bosso local government, Niger State, Nigeria. The study adopted a pre-test, posttest quasi-experimental design. The study used 135 students in junior secondary school III (JSS III). The experimental group consisted of 67 while control group consisted of 68 students. The researcher adopted and validated two instruments. These include: students self-concept toward geometry (SSTG), likert-type scales with reliability coefficient of 0.5 , geometry Achievement test (GAT), and five items theory question with reliability coefficient of 0.5 . The experimental period lasted for four weeks during which the control group was taught using discussion method while the experimental group was taught using active learning technique. Four research questions were answered and their corresponding four research hypotheses were tested. The research questions were answered using mean and standard deviation. Hypothesis testing was done using inferential statistic of t-test for equality of means of independent sample, Mann-Whitney $U$ test at $p \leq 0.05$, level of significance. There was a significance difference between the post-test mean scores of experimental and control group in favour of the experimental group. There was no significance difference in self-concepts of the subjects in the experimental group. It is recommended that active learning technique should be used in teaching mathematics.

Keywords : Active Learning, Constructivism, Flipped Classroom, Geometry, SelfConcept

\section{INTRODUCTION}

Mathematics is seen as an ingredient for the effective articulation of the abstract elements of science that gives impetus to the development of technologies. Mathematics is incorporated into the language of physical sciences and technology. Mathematics is useful in domestic and business deals, scientific

Copyright: $@$ the author(s), publisher and licensee Technoscience Academy. This is an open-access article distributed under the terms of the Creative Commons Attribution Non-Commercial License, which permits unrestricted non-commercial use, distribution, and reproduction in any medium, provided the original work is properly cited 
discoveries, technological breakthrough, problemsolving and decision making in different situations in life [1].Therefore, the importance of mathematics in general and geometry in particular cannot be overemphasized. Geometry plays a great role in determining the areas, volumes, and lengths of plane shapes and solids. One global application of geometry is in the Global Positioning System (GPS). GPS is a space based satellite navigation system that provides location and time information in all weather conditions anywhere on or near the earth [2].GPS employed coordinate geometry to calculate the distance between any two places. The coordinate geometry helps GPS to track transportation accidents and carry out rescue operations. The coordinate geometry also aids GPS in enhancing flight security, weather forecasting, earthquake monitoring, environmental protection and to determine the location of terrorist attacks.

To become global leaders and valuable citizens of today and tomorrow and to have a broader understanding of the world, students must learn to be independent and critical thinkers. Similarly, they must be able to: demonstrate deep conceptual understanding of their chosen discipline, approach challenges with curiosity, critical thinking and creativity, innovatively apply their skills to tackled complex real-world problems and developed as independent learners with high self-efficacy [3], [4]. The understanding of geometry will avail the students afore mentioned trait. However, the studies of [5] and [6] have confirmed that geometry is one of the topics among the abstract and complex aspects of mathematics that students find difficult to learn.

Research studies have shown that the traditional teaching methods have failed to develop the above mentioned skills [7] and [8]. However, [9] advocated for new methods of teaching mathematics that will be learner-centered and activity based. Similarly, [10] have argued that students should be nurture to develop $21^{\text {st }}$ century skills so as to be effective and succeed in this new information-based and highly technological society. These skills include: critical thinking, problem solving, collaboration across network, initiative, accessing and analyzing information and curiosity [11].These skills are seen as instrumental in active learning strategy approaches that is based on constructivist learning theory.

Constructivist viewed learning as an active process, arranged and systematic, and involves the construction of the individual's meaning through a relevant previous experience. Constructivist assumes that individual knowledge does not exist outside the mind, but is actively built in mind through real experience [12]. Similarly, constructivists argue that knowledge is not independent of people and constructing knowledge means that students are active participants in a learning process by seeking to find meaning in their experiences.

Simply put active learning is any instructional method that engages students in the learning process. This engagement requires students to do meaningful learning activities, collaborating with peers and think about what they are doing. Active learning is an instructional technique that engaged students in problem solving, answering questions, formulating questions of their own, discussing, explaining, debating and brainstorming during class lesson or activities [13].

Active learning is increasingly being recognized as a key component that may benefit students in achieving better mathematics results [8] and [14]. From the review of literatures, active learning has been shown to have reduces students' anxiety and increases their confident in learning [15]. This strategy has proved to accommodate mixed-ability group and benefit students of different learning styles [16]. In active learning, students are more likely to think, criticize and ask questions. Active learning 
activities can expose students to discussions, debates, collaboratively in learning, and sharing opinions [17]. Active learning increases student's metacognitive skills, critical thinking, inventive thinking and problem-solving skills [18]. So also active learning increases student's self-concept and relates to student's self-efficacy [19] and [20].

In related development, mathematics educators have attached great importance to affective factors of learning, and one of the most important and stable indicators of affective student attributes is selfconcept. Self-concept is the way an individual thinks, feels, acts, values and evaluates him or herself in relation to learning or performance. According to [21] self-concept affects many critical behaviors of the students such as effort to learn, determination when confronted by a problem and participation in the lesson. Self-concept in mathematics can be defined as students' ratings of their skills, ability, enjoyment, and interest in mathematics. It is seen as an essential factor in their achievement in mathematics [22]. Studies of [22] and [23] have shown that there was a significant positive correlation between the selfconcept and the mathematics achievement of students. It was based on the aforementioned that this study investigated the effect of active learning technique on self-concept and academic achievement in geometry among junior secondary school students.

\section{Objective of the Study}

The main objective of the study is to investigate the effect of active learning technique on self-concept and academic achievements of Junior Secondary School students in geometry. Specifically, the study seeks to find:

i. The students' achievement in geometry when instructed using active learning technique and when instructed using lecture method. ii. If there will be any change in self-concept of students taught geometry using active learning technique and those taught using lecture method

\section{Research Questions}

The following research questions guide the study.

- What are the mean achievement scores of students taught geometry using active learning technique and those taught using lecture method?

- Will there be any change in self-concept of students taught geometry using active learning technique and those taught using lecture?

\section{Research Hypotheses.}

The following null hypotheses were formulated and tested at $\mathrm{p}<0.05$

$\mathrm{HO}$ : There is no significant difference between the mean achievement scores of JSS III students taught geometry using active learning and those taught using lecture method.

$\mathrm{HO}_{2}$ : There is no significant change in self-concept of JSS III students taught geometry using active learning and those taught using lecture method.

\section{Concept of Active Learning}

Active learning strategy is any learning activity that engages students in active activities such as writing, discussing with each other in small or large groups, reading, exploring, explaining and clarifying the purpose of activities. The roles of the teacher in active learning include but not limited to the following:

i. Make constructive use of students' prior knowledge, ideas, and interests. ii. Guide students on how to reflect on their thinking in order to set goals, recognize when they do not understand, and adapt as necessary. iii. Explain and clarify the purpose of activities. iv. Allow students to work together in 
profitable way. v. Motivate students to exchange reflective ideas. vi. Motivate students to discuss their understanding. vii. Eliminate the phenomenon of fear from failure. viii. Allow students to evaluate their performance [16]. Similarly, students engaged in active learning often are: i. talking with each other in small groups or large discussions; ii. developing skills rather than memorizing information; iii. using higher order thinking; iv. doing something physical; v. constructing knowledge or artifacts [24 \& 25].

\section{Method and Material}

A quasi-experimental design of non-randomized pretest, post-test control group was adopted for the study. Intact classes were used so as to avoid disrupting the school arranged programmed. The population of this study consists of all public junior secondary schools class of (JSS III) students in Bosso Local Government Area of Minna, Niger State. This consisted of 1507 male and 1216 female. Multistage sampling procedure was adopted. In the first stage, the cluster sampling was used to group the schools according to location. In the second stage two schools, one from each cluster were randomly chosen. In the third stage one school was randomly assigned as experimental and the other as control using flipping of coin. The sampled participants consisted of 68 students in the experimental and 67 students in the control group respectively.

Mathematics Self-concept Questionnaire developed by [22] was adapted. The Mathematics Self-concept Questionnaire contains thirteen items that assess three major subscales: (a) competence component, (b) affective component, and (c) comparison component. The competence component assessed the students' perceptions of their mathematical skills and ability. Sample illustrative items of this subscale were: "I get good grades in mathematics" and "I learn things quickly in mathematics. The affective component investigates the students' interest in mathematics. Sample illustrative items of this subscale were: "I enjoy doing work in mathematics" and "I am interested in mathematics." The comparison component evaluates students' mathematics learning from the viewpoint of social comparison with their classmates. Sample illustrative item of this subscale is: "Compared to my classmates, I'm good at mathematics". The students were asked to rate the questions on a 5-point likert scale with response categories of: Never (1), Rarely (2), Sometimes (3), Usually (4), Always (5). Mathematics Self-concept Questionnaire has Cronbach's alpha reliability coefficient of 0.84 .

The geometry achievement test (GAT) was used to measure students' performance in geometry. This consists of five essay questions drawn from Basic Education Certificate Examination (BECE) and general mathematics textbook. The initial GAT was 8 items which later was reduced to 5 in the process of face validation by 3 experts and item analysis to determine its difficulty and discrimination power of each item. The test-retest method of reliability was used and Cronbach's Alpha of 0.720 was obtained.

Flipped classroom form of active learning as suggested by [26] and [27] was used to instruct the experimental group. In the inverted (or flipped) classroom environment, the facilitator presents basic definitions, examples, proofs, and heuristics of the concept to be learn to students in assigned readings or problems to be solved prior to attending class. This will cover the lower levels of cognitive domain, that is, remembering and understanding [28]. Thus, the class time will become available for active learning tasks that directly engage students. The facilitator then used think-pair-shares tasks during this time. Here the facilitator provides students with a short task such as doing a computation, completing a step in a proof, generating one or more examples. After providing the students with two to three minutes of time to independently consider the task ("think"), students take two minutes to compare their answers with other students sitting nearby ("pair"). Finally, some or all of the students are asked to share their answers in 
some manner, either with the groups next to them or with the entire class ("share"). The time the student stays in the classroom is used to carry out discussions, solve problems, conduct hands-on activities, and provide guidance to them [29].

\section{RESULTS}

Table 1: T- test Comparison of Pre-test Scores of Control and Experimental Groups

\begin{tabular}{|c|c|c|c|c|c|c|c|}
\hline Groups & $\mathrm{N}$ & Mean & $\mathrm{SD}$ & $\mathrm{df}$ & $\mathrm{t}$-cal & $\mathrm{t}$-crit & p-value \\
\hline \multirow[t]{2}{*}{ Experimental } & 67 & 41.68 & 5.98 & & & & \\
\hline & & & & 133 & $1.014^{* *}$ & 1.96 & 0.05 \\
\hline Control & 68 & 40.72 & 6.12 & & & & \\
\hline
\end{tabular}

** not significant at 0.05 level of significance

Table 1 shows the t-test comparison of the mean score of control and experimental group at pre-test. From the table, there is no statistical different between the mean scores of experimental group (41.68) and that of the control group (40.72) at 0.05 level of significance ( $\left.t_{c a l}=1.014<t_{c r i t}=1.96, \mathrm{df}=133\right)$. Hence the two groups are equivalent at the beginning of the experiment.

Ho1: There is no significant difference between the mean achievement scores of JSS III students taught geometry using active learning technique and those taught geometry using conventional teaching method. To test this hypothesis the post-test scores of the students in the experimental and control groups were compared using $\mathrm{t}$-test, table 2 below showed the result obtained.

Table 2 : Summary of t-test for post-test of experimental and control groups

\begin{tabular}{lccccccc}
\hline Groups & $\mathrm{N}$ & Mean & $\mathrm{SD}$ & $\mathrm{df}$ & $\mathrm{t}$-cal & $\mathrm{t}$-crit & $\mathrm{p}$-value \\
\hline Experimental & 67 & 50.92 & 15.31 & & & & \\
Control & 68 & 33.69 & 13.63 & & & & \\
\hline
\end{tabular}

*significant at $\mathrm{p}<0.05$

From Table 2, the p-value obtained was 0.001 which is $<0.05$, the value of $\mathrm{t}$-calculated of 6.92 which is found to be higher than $\mathrm{t}$ - critical of 1.96 further confirms the result. The null hypothesis was therefore, rejected. This means that there was significant difference between achievement of the experimental groups with mean of 50.92 and control groups with mean of 33.69. The result thus showed that active learning technique is more effective in enhancing student's achievement in geometry concept.

Ho2: There is no significant difference between the mean self-concept scores of JSS III students taught geometry using active learning technique and those taught geometry using conventional teaching method.

To test this hypothesis the self-concept ranked scores of both experimental and control groups were subjected to Mann-Whitney U-test. The result is shown in Table 3 below. 
Table 3 : Mann-Whitney U-test on self-concept of JSS III Students.

\begin{tabular}{cccccccc} 
& Group & $\mathrm{N}$ & Mean Rank & Sum of Rank & $\mathrm{U}$ & $\mathrm{Z}$ & $\mathrm{P}$ \\
\hline Self-concept & $\mathrm{E}$ & 67 & 91.09 & 5921.00 & 774.00 & -6.614 & .000
\end{tabular}

Table 4.6 showed that the result of the MannWhitney U-test applied to the self-concept score of students in experimental and control groups revealed a statistically significant difference at the level of $\mathrm{p}<0.05(\mathrm{z}=6.614 ; \mathrm{p}=.000<0.05)$.

The rank average of the self-concept scores of the experimental group students was 91.09; while the students in the control group had self-concept score rank average of 46.56. The result thus showed that active learning technique is more effective in enhancing students' self-concept towards geometry.

\section{DISCUSSIONS}

The discussions of the findings of the present study is here been presented in relation to both research questions and hypotheses. The result from statistical analysis relating to hypothesis one as shown in Table 2 revealed that the experimental group that was exposed to active learning technique perform better than the control group that was exposed to conventional method. The finding of this study collaborate with the studies of [8] and [14] whose studies showed that students' performance in geometry improved after instruction with active learning. It was also supported by the finding of [29] who reported that active learning using flip teaching as tool improved students' performance. The result from Mann-Whitney U-test relating to hypothesis two as shown in Table 3 revealed that the experimental group that was exposed to active learning has higher self-concept when compared to the control group. This finding is in agreement with the findings of [19] who found insignificant difference in student's self-concept of foreign language students exposed to active learning compared to those exposed to traditional method. Similarly, the study of [20] showed that there is significant relationship between active learning and self-efficacy of higher education students.

\section{v. CONCLUSION}

The conclusions of this study are made based on the investigated problems. The results of data analysis clearly indicated that students in experimental group achieved higher in the geometry than students in the control group. Again the experimental group taught with active learning technique showed more of selfconcept compared with those in the control group taught with conventional method. Therefore the active learning using instruction flipped classroom is effective in teaching and learning mathematics, particularly geometry aspects.

\section{REFERENCES}

[1]. Yahya, M. M., Calkin, S. M., \& Casmir, R. O. (2020). Assessing Students' Performance in Mathematics in Tanzania: The Teacher's Perspective. International Electronic Journal of Mathematics Education. 5 (3), 1-28. https://doi.org/10.29333/iejme/7994

[2]. Ziaul, H. (2016). Basic concept of GPS and its applications. Journal of Humanities and Social Science. 21(3), 31-37

[3]. Chionson, M.M., Aligbe, S.O. \& Azuka, B.F. (2016). Enculturation of 21st Century learning skills on secondary school students in mathematics for Digital age. Journal of 
Mathematical Sciences Education. A Journal of National Mathematical Centre, Abuja 4(1), 591600

[4]. Zhang, T. (2016). Developing pedagogies as means for improving quality: Learning and Teaching as a European priority. 11th European Quality Assurance Forum Ljubljana, 7 - 19 November 2016

[5]. Pavethira, S. \& Leong, K. E. (2017). Students' performance in geometrical reflection using Geo- Gebra. Malaysian Online Journal of Educational Technology, 5 (1), 65-77

[6]. Fabiyi, T.R. (2017). Geometry Concepts in Mathematics Perceived Difficult To Learn By Senior Secondary School Students in Ekiti State, Nigeria. Journal of Research and Method in Education, 7(1), 83-90.

[7]. Hamza, F.M. \& Mohammed, U. (2018). Nurturing creativity in STEM education classrooms for global competitiveness and economic growth. In In A. S. Ifamuyiwa (Eds). Science Teachers Association of Nigeria (STAN) proceedings (pp. 25-32)

[8]. Alharbi, A. A \& Yang, C. (2019). Applying Active Learning in Classroom Environment: Implications for Mathematical Achievement. Journal of International Business Research and Marketing 4(2), 43- 51

[9]. Azuka, B.F., Durajaiye,D.S., Okwuoza, S.O., and Jekayinfa, O. (2013). Attitude of Primary School Mathematics Teachers Towards the use of Activity-based Learning Method in Teaching Mathematics in Nigeria.International Journal of Education Learning and Development, 1(1), 2236

[10]. Brady, C., Earness, C., \& Lesh, D. (2015). Connecting real-world and in-school problemsolving experiences. Quadrante 24(2), 5-36

[11]. Gravemeijer, K., Stephen, M., Cyril, J., Lin, F \& Minoru, O. (2017). What mathematics education may prepare students for the society of the future? Journal of Science and Mathematics Education. 15 (1), 105-123

[12]. Bada, O. \& Olusegun, S. (2015). Constructivism learning theory: A paradigm for teaching and learning. IOSR-JRME, 5(6), 66-70. Doi: 1 0.9790/7388-05616670.

[13]. Benjamin, B., Bremser, P., Art, M. D., Lockwood, E. \& White, D (2019). What Does Active Learning Mean For Mathematicians? Notices of the American Mathematical Society (AMS) 64(2) 124-129

[14]. Aji, C.A. and Khan, M.J. (2019) The Impact of Active Learning on Students' Academic Performance. Open Journal of Social Sciences, 7 , 204-211.

https://doi.org/10.4236/jss.2019.73017

[15]. Cooper, K. M.., Downing, V. R., \& Brownell, S. $\mathrm{E}$, (2018) The influence of active learning practices on student anxiety in largeenrollment college science classrooms. International Journal of STEM Education 5 (23),1-18. https://doi.org/10.1186/s40594-0180123-6

[16]. Melaku, T. (2020). Implementation of active learning methods in mathematics classes of Woliso town primary schools, Ethiopia. International Journal of Science and Technolog Education Research , 11(1), 1-13. DOI: 10.5897/IJSTER2019.0461

[17]. Celik, H. C. (2018). The effects of activity based learning on sixth grade students' achievement and attitudes towards mathematics activities. EURASIA Journal of Mathematics, Science and Technology Education, 2018, 14(5), 1963-1977.

[18]. Pantiwati, Y., \& Husamah. (2017). Self and peer assessments in active learning model to increase metacognitive awareness and cognitive abilities. International Journal of Instruction, 10(4), 185202. https://doi.org/10.12973/iji.2017.10411.

[19]. Mustafa, E. R., Altunay, U. \& Yurdabakan, I. (2012). The effects of active learning on foreign language self-concept and reading 
comprehension achievement. International Journal on New Trends in Education and Their Implications 3 (4), 43-58

[20]. Chan, Y. F., Siti F. D., Suthagar, N., Gurnam, K. S., Lee, L.F., \& Khor, M. K. (2015). Relationship between active learning and self-efficacy among students in higher education. International Academic Research Journal of Social Science, 1(2), 139-149

[21]. Erdogan , F \& Sengul, S. (2014). A study on the elementary school students' mathematics selfconcept. Procedia - Social and Behavioral Sciences 152, $596-601$

[22]. Ching,Y. L. \& Kung, H. (2018). Math SelfConcept and Mathematics Achievement: Examining Gender Variation and Reciprocal Relations among Junior High School Students in Taiwan. EURASIA Journal of Mathematics, Science and Technology Education, 14(4),12391252

[23]. Kamoru, U., \& Ramon, O. G. (2017). Influence of self-concept, study habit and gender on attitude and achievement of secondary school students in mathematics. Journal for Leadership and Instruction, 16(1), 49-52.

[24]. Hodges, L. C (2020). Student Engagement in Active Learning Classes. Active Learning in College Science 1(1), 27-41)

[25]. Ahmad, A. (2017). The Impact of the Use of Active Learning Strategies in the Development of Mathematical Thinking among Students and the Trend Towards Mathematics. Journal of Education and Practice, 8(36), 12-18

[26]. Mustafa, C. \& Ziya, A. (2017). An Innovative Learning Model in Digital Age: Flipped Classroom. Journal of Education and Training Studies, 5 (11), 189- 198

[27]. Smallhor, M. (2017). The flipped classroom: A learning model to increase student engagement not academic achievement. STARS Conference Special Issue, 8 (2), 43-53
[28]. Johnston, B. M. (2017). Implementing a flipped classroom approach in a university numerical methods mathematics course. International Journal of Mathematical Education in Science and Technology, 48(4), 485- 498. doi: 10.1080/0020739X.2016.1259516

[29]. Bachiller, P. \& Badía, G (2020), The Flip Teaching as Tool to Improving Students' Sustainable Learning Performance in a Financial Course. Sustainability, 12, 9998; doi:10.3390/su12239998

\section{Cite this article as :}

Aliyu Alhaji ZAKARIYYA, Ahmad Umar MANKO, Kure D. ISAH, Ochidali Apollos ADUOJO, "Effect of Active Learning Technique on Self-Concept and Academic Achievement Among Juniour Secondary School Students in Geometry in Bosso, Niger State, Nigeria", International Journal of Scientific Research in Science and Technology (IJSRST), Online ISSN : 2395-602X, Print ISSN : 2395-6011, Volume 8 Issue 6, pp. 170-177, November-December 2021. Available at doi $\quad$ : https://doi.org/10.32628/IJSRST218576 Journal URL : https://ijsrst.com/IJSRST218576 